\title{
Ultra-infra: Becoming skin
}

\author{
Ian Truelove \\ The Leeds School of Art, Architecture and Design \\ Leeds Beckett University \\ Broadcasting Place \\ Leeds LS2 9EN, UK \\ i.a.truelove@leedsbeckett.ac.uk
}

\section{INTRODUCTION}

This demonstration showcases outcomes from a program of research that seeks to expand the practice of painting through the exploitation of new digital technologies. Through virtual reality and digital painting processes, this research interrogates the nature of materiality by considering the hidden realities of human skin. The demonstration is in the form of a VR-based artwork delivered on a Windows Mixed Reality headset.

\section{BECOMING SKIN}

The notorious 'collapse of the wave-function' is nothing but the updating of an agent's state assignment on the basis of her experience. (Fuchs, Mermin \& Schack 2013)

To me Art's subject is the human clay. (Auden 1937)

I am concerned with a traditional pursuit for a modernist painter: I am attempting to make the invisible world visible. I use an iPad, the Procreate painting application and an Apple Pencil rather than canvas, acrylics and a hairy brush, but I still think of myself as a traditional painter. I'm inspired by ideas from quantum theory, but I'm not too concerned about my shaky comprehension of this wonderful description of a hidden reality. When I am painting I try to hold in my head the notion that a minuscule entity that forms part of a human face is not manifest, but exists as an abstract mathematical description of a quantum object: the notorious 'wave function'. Sometimes I try to imagine the wave function of a sub-atomic entity that is part of an outer cell of the skin, and sometimes I think about the wave function of a photon interacting with the outermost boundary of the face, at the point where it meets the 'not-face'. The observer is often quoted as the thing that collapses the wave function into something sensible, but this needn't be the eye of a human. It is the interaction of the wave function with any aspect of the classical world that causes its collapse, and precisely how it collapses is determined by the thing it collapses into: the observer may not be sentient. If the classical human eye and brain collapse the wave function, then this creates a reality that makes sense within a human frame of reference. If the collapse of the wave function of an isolated sub-atomic entity of skin is caused by classical skin itself - skin as observer then what might that look like? If invisible skin is perpetually collapsing into visible skin, how might that manifest itself? I strive to paint that in an attempt to find new ways to resolve the human clay.

\footnotetext{
A plane of immanence can be conceived as a surface upon which all events occur, where events are understood as chance, productive interactions between forces of all kinds. As such, it represents the field of becoming, a 'space' containing all of the possibilities inherent in forces. (Stagoll 2005, p. 204)
}

An alternative way to think of the wave function is to draw on the philosopher Gilles Deleuze's notion of 'the plane of immanence'. The wave function is everywhere now: it is immanent. It sustains the universe and is all pervasive. The wave function is a mathematical reality, but it is only when we cut a plane across it through an act of observation that we can glimpse it. I am interested not just in the point of observation, but just beyond that point, What is collapsing? rather than what has collapsed? Considering a whole face collapsing simultaneously, what I am imagining and painting is a plane of imminence: becoming skin. I invite you to examine the resulting visuospatial research outcomes in my virtual world. 


\subsection{Smooth and Striated}

Cezanne spoke of the need to no longer see the wheat field, to be too close to it, to lose oneself without landmarks in smooth space. Afterward, striation can emerge: drawing, strata, the earth, 'stubborn geometry', the 'measure of the world'... The striated itself may in turn disappear in a 'catastrophe', opening the way for a new smooth space, and another striated space... (Deleuze \& Guattari 1987)

My work is firmly rooted in the histories, traditions, theories and practices of painting, and I enjoy trying to make use of philosophy in the development of my thinking. Although my practice always comes first, I have found lots of things in the world of theory that resonate with my artistic research. My interest in the works of the $20^{\text {th }}$ century continental philosophers Jean-François Lyotard and Gilles Deleuze has allowed me to consider my practice from different perspectives, and has enable me to craft some alternative analytical tools. Lyotard's writings on 'affect' have helped me to maintain a healthy balance between words, things and sensations in my research, and I have taken Deleuze's 'smooth' and 'striated' mantras quite literally and used them as alternative methods for categorising paintings that match up with my own values. Freed from the dogma of historicism, I have indulged in such sins as allowing myself to love a Bouguereau for its super-smooth porcelain rendering of skin. I have feasted on the smooth flesh of Ingres, and moved through Seurat's pixel-like divisionism to early smooth Lucian Freud, then on to late striated Freud and Bacon. Then a revelation: I saw an original Auerbach. Then a Kossoff. I had a transcendental moment so intense when looking at a Kossoff in York Art Gallery that I thought I was having a mini- stroke. In the Courtauld Gallery, Kossoff's Head of Seedo (1964) made my stomach churn, like l'd met a celebrity. When looking at this extreme striation up close I lost all sense of scale and orientation and I felt like I was flying over a landscape. Paint is rarely as explicit as in a Kossoff, but I no longer saw the painting. My York epiphany was at the early stages of developing this VR artwork, and I knew this was the answer. Up close to, and stood back from a Kossoff were two different experiences, very similar to my experiences when crafting my original digital paintings of zooming into the pixels then zooming back out to see the whole.

Deleuze gave me the scythes I needed to hack through the wheat fields of history, and I found Kossoff and Auerbach there. Their artworks provide the best painterly reference point for the virtual reality artwork I present to you.

\section{REFERENCES}

Auden, W. H. (1937) Letter to Lord Byron, Letters from Iceland. Faber \& Faber, London, p.103.

Deleuze, G. and Guattari, F. (1987) A Thousand Plateaus. Translated from the French by $B$. Massumi, Continuum, London, pp.161-544.

Fuchs, C. A., Mermin, D., and Schack, R. (2013) An Introduction to QBism with an Application to the Locality of Quantum Mechanics. Quant-ph, Arxiv, pp.2-34.

Kossoff, L. (1964) Head of Seedo [painting]. Held at Courtauld Gallery, London.

Stagoll, C. (2005) In A. Parr (ed.), The Deleuze Dictionary. Edinburgh University Press, Edinburgh, pp.204-206. 